\title{
Vertical migration of blue crab Callinectes sapidus megalopae: implications for transport in estuaries
}

\author{
Eugene J. Olmi III* \\ Virginia Institute of Marine Science, The College of William and Mary, Gloucester Point, Virginia 23062, USA
}

\begin{abstract}
Following larval development in coastal waters, postlarvae (megalopae) of the blue crab Callinectes sapidus Rathbun enter inlets and, against the net seaward flow of estuarine waters, move upstream to juvenile habitats. Abundance and vertical distribution of blue crab megalopae in the York River, Virginia, USA, a subestuary of Chesapeake Bay, was quantified to examine the hypothesis that megalopae are not transported simply as passive particles, but display behaviors that augment their immigration. Megalopal abundance and depth distribution and environmental variables were measured at shallow ( 3 to $4 \mathrm{~m}$ ) sites in 1988 and 1989 and at a deep $(10 \mathrm{~m})$ site in 1990. Megalopae were more abundant in the water column during flood than ebb, indicating a net upstream flux of megalopae. Densities were always low during ebb. Highest densities occurred during night flood tides, when megalopae were aggregated near the surface. During day flood tides, megalopae were generally less abundant and distributed deeper in the water column. Occasionally, however, they were abundant during day flood, concentrated near the bottom in deep water. At shallow sites, megalopae were never abundant during day, apparently not ascending into well-lit waters. Abundance and depth distribution of megalopae were not affected by current speed, wind speed, water temperature or salinity. A conceptual model of vertical migration of estuarine blue crab megalopae is presented. Megalopae which behave according to this model should lower their susceptibility to predation in the water column by selectively utilizing flood currents to rapidly reach juvenile nursery grounds while avoiding well-lit waters.
\end{abstract}

KEY WORDS: Blue crab - Megalopae $\cdot$ Transport $\cdot$ Vertical migration

\section{INTRODUCTION}

Three general life history strategies are evident among species that have planktonic larvae and are dependent on estuarine nursery areas: spawning in coastal waters with migration of larvae or juveniles to estuaries; spawning and retention of larvae within the estuary; and spawning within the estuary with export of larvae to coastal waters and subsequent return of postlarvae or juveniles. In all cases, immigration into or retention within estuaries of early life history stages is challenged by the net export of estuarine water.

Whereas the transport of some estuarine and coastal invertebrate larvae may be modeled as passive parti-

\footnotetext{
-Present address: Virginia Graduate Marine Science Consortium, University of Virginia, Madison House, 170 Rugby Rd, Charlottesville, Virginia 22903, USA
}

cles (deWolf 1974, Boicourt 1982, Stancyk \& Feller 1986), larvae of fishes and many invertebrates exhibit behaviors which enhance transport to suitable nursery habitats (Boehlert \& Mundy 1988, Epifanio 1988). One such behavior, depth regulation, can substantially alter the path of transport in an environment of vertical current shear. In particular, weakly swimming larvae (or juveniles) may effect upstream transport in estuaries via tidally-timed vertical migration - moving into the water column during flood and descending to weaker currents near the bottom during ebb (selective tidal stream transport) - or by remaining in landward flowing bottom water of an estuary with net 2-layered circulation.

Active changes in depth distribution of these meroplankters may vary from simple ontogenetic changes in depth distribution (Bousfield 1955) to complex responses (which may also vary with ontogenetic 
development) to a host of environmental stimuli in the estuary or near-shore region (Fortier \& Leggett 1983, Sulkin 1984, Forward 1985, Cronin \& Forward 1986, Laprise \& Dodson 1989).

Boehlert \& Mundy (1988) recognized 2 stages in the migration of shelf-spawned larvae toward estuarine habitats: cross-shelf transport of larvae to the nearshore zone, followed by accumulation of larvae near inlets and passage through them. Since the physical factors involved in these 2 processes differ, each requires specific and distinct behaviors by the larvae to reach juvenile nursery grounds.

Larvae of the blue crab Callinectes sapidus are hatched in the lower estuary, ascend to the surface, and are flushed out of the estuary into coastal waters (Dittel \& Epifanio 1982, McConaugha et al. 1983, Provenzano et al. 1983, Epifanio et al. 1984). During their approximately 30 to $50 \mathrm{~d}$ development, the larvae remain in surface waters and may be transported considerable distances ( 30 to $80 \mathrm{~km}$ ) from shore (Nichols \& Keney 1963, Smyth 1980, McConaugha 1988). In the mid-Atlantic Bight during summer, wind-driven surface currents (to the north) counter the general southerly flow on the shelf and may retain larvae in the vicinity of the estuary of their origin (Boicourt 1982, Johnson et al. 1984, D. R. Johnson 1985, Epifanio 1988, Epifanio et al. 1989).

Metamorphosis to the postlarval stage, the megalopa, occurs in shelf waters, and blue crab megalopae remain concentrated in the neuston layer (Smyth 1980 , D. F. Johnson 1985, McConaugha 1988). In concordance with these field observations, laboratory studies revealed negative geotaxis and high barokinesis in blue crab megalopae - behaviors that maintain megalopae near the surface (Sulkin \& Van Heukelem 1986).

Noting that peak concentrations of blue crab megalopae were in surface waters $33 \mathrm{~km}$ off the mouth of Chesapeake Bay, D. F. Johnson (1985) suggested that, in the absence of strong onshore winds, recruitment to Chesapeake Bay must be by juvenile stages. Reinvasion of estuaries by juveniles also had been suggested for other areas (Tagatz 1968, Dudley \& Judy 1971); yet considerable evidence indicated that the megalopal stage was most responsible for estuarine immigration and colonization of nursery areas (Williams 1971 Meredith 1982, Epifanio et al. 1984, Olmi 1986, Mense \& Wenner 1989, Olmi et al. 1990, van Montfrans et al. 1990, Little \& Epifanio 1991).

Shanks (1988) suggested that megalopae may be transported toward shore in surface slicks over tidally forced, internal waves. Sulkin \& Van Heukelem (1986) posed 3 alternative hypotheses for immigration of blue crab megalopae: first, megalopae remain at the surface and are transported into estuaries by onshore winds, as suggested by D. F. Johnson (1985); second, megalopae may remain at the surface until they approach metamorphosis, then descend to landward-flowing bottom waters; and third, the 12 to $25 \%$ of megalopae observed near the bottom by D. F. Johnson may represent a steady state such that a constant portion of the population is subject to onshore transport in bottom waters.

Recent evidence indicates that wind-forcing and associated non-tidal inflow into estuaries is associated with increased settlement of blue crab megalopae (Goodrich et al. 1989, Little \& Epifanio 1991). Although wind-forcing may be an important mechanism that aggregates megalopae near inlets and possibly transports them through inlets, it is probably less important in the upstream migration of megalopae within tidally dominated estuaries. Blue crab megalopae must alter their surface-oriented behavior exhibited in coastal waters to allow migration up estuaries.

Limited support for transport of megalopae in bottom drift comes from field observations (Tagatz 1968, Sandifer 1973, 1975). Epifanio (1988) invoked landward transport of megalopae in bottom water as the most plausible mechanism of return, but noted that the speed of the net flow was extremely slow and that megalopae may augment their transport by vertical migration. Observations of greater abundance of megalopae during flood than ebb suggest that megalopae may employ selective tidal stream transport (Meredith 1982, Epifanio et al. 1984, Brookins \& Epifanio 1985, Olmi 1986, Mense \& Wenner 1989); yet, field studies have not produced evidence that tidally timed, vertical migration occurs.

In this 3 yr study, I examined the selective tidal transport hypothesis by investigating temporal variation in the abundance and vertical distribution of blue crab megalopae and related these patterns to environmental factors and transport processes in the York River, Virginia, USA.

\section{METHODS}

The study sites were located $11 \mathrm{~km}$ upriver from the mouth of the York River, a primary tributary on the western shore of lower Chesapeake Bay (Fig. 1). Tides in the York River are semi-diurnal, with a mean tidal range of $0.7 \mathrm{~m}$ at the mouth (Haas 1977). The lower portion of the river oscillates between conditions of vertical homogeneity (following spring tides) and stratification (Haas 1977).

The Chesapeake Bay is classified as a moderatelystratified estuary; at its mouth there is a net inflow of shelf water near the bottom and a net outflow of low density water near the surface (Pritchard 1967). The effect of this gravitational circulation extends well onto 
the continental shelf (Bumpus 1973). Long-term net flow varies spatially across the Bay mouth, largely due to Coriolis effects (Boicourt 1981, Goodrich 1988). Meteorological events can greatly alter exchange, producing inflow or outflow surges (Wang \& Elliot 1978, Wang 1979, Goodrich 1988).

1988 study. In 1988, I quantified the fine-scale vertical distribution of blue crab megalopae at a shallow ( 3 to $4 \mathrm{~m}$ ) site on the north shore of the York River (Fig. 1, Site A); this site concurrently serves for long-term studies of megalopal planktonic abundance and settlement (van Montfrans et al. 1990, Olmi 1993). Samples were collected during flood tide at the end of a pier extending approximately $100 \mathrm{~m}$ into the York River. Ebb tides were not sampled because currents were weak

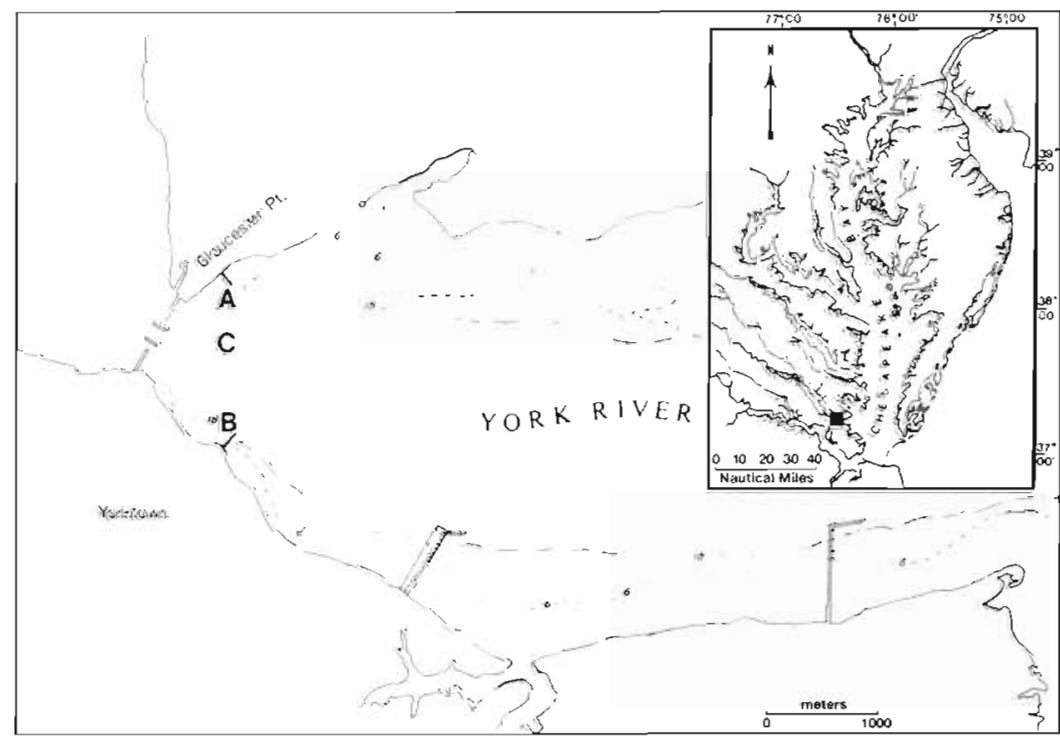

Fig. 1. Lower York River in the vicinity of Gloucester Point, Virginia, USA. Sites indicated are: A, 1988 study; B, 1989 study; C, 1990 study and variable during much of the ebb due to the constriction in the river at Gloucester Point (Fig. 1).

Megalopae were sampled with a vertical array of 5 plankton nets each measuring $50 \mathrm{~cm}$ high $\times 100 \mathrm{~cm}$ wide $\times 300 \mathrm{~cm}$ long, with mesh of $0.75 \mathrm{~mm}$. The nets were attached to 2 frames, each suspended from its own boom. Nets 1, 2 and 3 were attached to the first frame and sampled surface to $30 \mathrm{~cm}, 30$ to $80 \mathrm{~cm}$, and 130 to $180 \mathrm{~cm}$ depths (Net 1 was partially out of the water). The second frame, with Nets 4 and 5, was lowered to the substratum, and sampled depth strata of 150 to $100 \mathrm{~cm}$ above the bottom and 50 to $0 \mathrm{~cm}$ above the bottom. Water depth varied from 3.0 to $4.0 \mathrm{~m}$ during sampling. When water depth was less than $3.3 \mathrm{~m}$, Nets 3 and 4 overlapped, with Net 3 approximately 1 to $1.5 \mathrm{~m}$ up current of Net 4 . At the maximum depth of $4.0 \mathrm{~m}$, there was a vertical distance of $0.7 \mathrm{~m}$ between Nets 3 and 4 . Flowmeters (General Oceanics Model 2030 with low speed rotor) suspended in the mouth of each net and between Nets 2 and $3(105 \mathrm{~cm}$ below surface) provided information for calculation of water volumes sampled and current speeds.

Each deployment (set) of the net array lasted $30 \mathrm{~min}$. The net array was deployed 4 times during a given flood tide, beginning $1 \mathrm{~h}$ after slack-before-flood with approximately $1 \mathrm{~h}$ between sets. Water temperature and conductivity (for salinity) were measured every 6 min at a depth of $2 \mathrm{~m}$ above the bottom with a CTD meter. Solar irradiance, wind direction and wind speed were also measured at the Virginia Institute of Marine Science meteorological station (approximately $300 \mathrm{~m}$ away and $30 \mathrm{~m}$ above sea level). I used the first measurement of physical data recorded after net deployment.
Plankton samples were rinsed onto a $0.5 \mathrm{~mm}$ sieve and preserved in $5 \%$ formalin. Callinectes megalopae were sorted in the laboratory with the aid of a lighted magnification glass. Besides $C$. sapidus, one other species of Callinectes (C. similis) occurs infrequently in Chesapeake Bay (Wass 1972). Megalopae of C. similis are generally restricted to more saline waters than occur at the sampling site (Stuck \& Perry 1981, Mense $\&$ Wenner 1989) and have not been collected in samples from the York River (Johnson 1982, Maris 1986). I therefore assumed that all Callinectes megalopae were those of $C$. sapidus.

Five separate flood tide periods were sampled. On 14 and 21 October, all sets of the net array were conducted during darkness. Three consecutive flood tides were sampled 24-25 October; these flood periods encompassed dusk on 24 October and dawn and dusk on 25 October.

1989 study. In 1989 I examined the vertical distribution of blue crab megalopae during nighttime flood and ebb tides at a shallow water location. Sampling was conducted on 16-17 October from a pier on the south side of the York River, across from the pier used in 1988 (Fig. 1, Site B). Water depth during sampling varied from 2.9 to $3.7 \mathrm{~m}$.

Sampling gear was identical to that used in 1988 , except that 4 rather than 5 nets were deployed. Depth strata sampled were: Net 1, water surface to $30 \mathrm{~cm}$; Net 2, 30 to $80 \mathrm{~cm}$ depth; Net 3,150 to $100 \mathrm{~cm}$ above the bottom; and Net 4,50 to $0 \mathrm{~cm}$ above bottom. At the minimum water depth of $2.9 \mathrm{~m}$, Nets 2 and 3 were $60 \mathrm{~cm}$ apart, and at the maximum depth of $3.7 \mathrm{~m}$, Nets 2 and 3 were separated by $140 \mathrm{~cm}$. The net array was deployed for $30 \mathrm{~min}$ during each set. A flowmeter 
was suspended in the mouth of each net, and one was suspended in the water column, $1 \mathrm{~m}$ below the surface, to measure current speed. Surface water temperature and salinity were measured using a stem thermometer (to $0.1^{\circ} \mathrm{C}$ ) and refractometer (to $0.5 \mathrm{psu}$ ), respectively. Solar irradiance, wind speed and wind direction were measured every $6 \mathrm{~min}$ at the Virginia Institute of Marine Science (Site A). Samples were processed like those in 1988.

Sampling commenced during early flood at dusk (18:57 h EST) on 16 October, and the net array was deployed 5 times during flood ( $1 \mathrm{~h}$ between sets). The tide began to ebb at $23: 45 \mathrm{~h}$ and the nets were deployed at 00:30, 01:30 and 02:30 h on 17 October. The net array was deployed at 03:30 h, but the ebb current was too weak for quantitative sampling, and remained weak through the remainder of the ebb. Thus, the 1989 collections consisted of 5 sets of the 4net array during flood ( 1 at dusk and 4 during darkness) and 3 sets during ebb (all during darkness).

1990 study. In 1990 the abundance and vertical distribution of blue crab megalopae in deeper water (10 to $13 \mathrm{~m}$ ) of the York River were examined to determine if distribution patterns were similar in deep water to those observed the previous 2 years at shallow sites, and to relate patterns of megalopal abundance and vertical distribution to light, tidal stage and watercolumn characteristics.

The site was north of the ship channel in the York River, between the 2 previous sites (Fig. 1, Site C). Sampling was conducted during 4 tidal cycles; beginning with slack-before-flood the morning of 8 October and continuing through the morning of 10 October, samples were collected during slack tide (at the surface) and at 2 and $4 \mathrm{~h}$ after slack tide.

Megalopae were collected in 4 plankton nets $(0.75 \mathrm{~mm}$ mesh and equipped with flowmeters) deployed from an $8.2 \mathrm{~m}$ vessel. A $0.5 \mathrm{~m}$ high $\times 1.0 \mathrm{~m}$ wide net fixed to a bow-mounted frame sampled the upper $37 \mathrm{~cm}$ of the water column. The other 3 nets, attached to $1.0 \mathrm{~m}$ diameter rings equipped with flowmeters, were towed behind the vessel at depths of 2,5 and $10 \mathrm{~m}$. Engine RPM was held constant for all tows, and speed through the water was approximately 2 knots. Nets were towed for 10 min during each set, and vessel speed was reduced to 0.5 knot during deployment and retrieval of nets. Samples were handled as previously described.

Prior to net deployment and while moored to a fixed station, current speed and direction were measured at depths of 0.3 (near surface) $2,4,6,8$ and $10 \mathrm{~m}$ with an Interocean S-4 current meter. Ten current velocity measurements per second were averaged over $15 \mathrm{~s}$ intervals; the meter was held for 2 min at each depth, and reported velocities represent the vector average of
$15 \mathrm{~s}$ interval readings over the middle $1 \mathrm{~min}$ at each depth.

Water-column profiles of temperature and salinity were measured (Applied Microsystems CTD probe), and the density structure of the water column was characterized by calculating $\sigma_{t}$ from the temperature and salinity profiles. An index of stratification (S) was calculated as:

$$
S=\Delta \sigma_{\mathrm{t}} / Z
$$

where $\Delta \sigma_{t}$ is the change in density from surface to bottom, and $Z$ is the depth of the water column (Tremblay \& Sinclair 1990). The maximum change in $\sigma_{\mathrm{t}}$ over a $1 \mathrm{~m}$ interval and the depth at which it occurred were also calculated. Measures of wind speed and direction, solar irradiance and tidal height were collected at Site A.

Data analysis. Density of blue crab megalopae in a given sample was expressed as the number of individuals per $10 \mathrm{~m}^{3}$ of water filtered (ind. $10 \mathrm{~m}^{-3}$ ). The degree of aggregation of blue crab megalopae in the water column was examined in 2 ways. First, I calculated the coefficient of variation (CV) of megalopal density among the depth strata in each set as a measure of the dispersion of megalopae in the water column (Tremblay \& Sinclair 1990). The CV increases with greater aggregation of megalopae.

Second, I compared the observed vertical distribution of megalopal densities from each set to expected distributions assuming even or random dispersion of megalopae. For comparison with a distribution of evenly dispersed megalopae, the expected number of megalopae in a particular net was calculated as follows (McCleave et al. 1987):

$$
E_{k}=\frac{W_{k}}{\sum W_{i}} N
$$

where $E_{k}$ is the expected number of megalopae in Net $k, W_{k}$ is the water volume filtered by Net $k, \Sigma W_{i}$ is the sum of water volume filtered in all nets, and $N$ is the total number of megalopae collected in all nets.

Observed and expected distributions were compared by chi-squared goodness of fit tests (Zar 1984, McCleave et al. 1987). The observed distribution of densities in each set were then compared to a distribution with the same mean and randomly distributed individuals (Ryan et al. 1985).

An estimate of the mean depth of megalopae in the water column was calculated as the weighted mean depth (Pearre 1973):

$$
\bar{D}=\frac{\sum n_{1} d_{i}}{\sum n_{i}}
$$

where $n_{i}$ is the density of megalopae in the $i$ th depth interval, and $d_{1}$ is the mid-depth of the $i$ th interval. 
Weighted mean depth is similar to 'larval center of mass' (Fortier \& Leggett 1983, Tremblay \& Sinclair 1990). Mid-depth was measured as depth from the surface. For 1988 and 1989 collections, $d_{i}$ of the lower nets (resting on the substratum) was measured at mean water height above the bottom (i.e. $3.5 \mathrm{~m}$ at Site $\mathrm{A}$ and $3.3 \mathrm{~m}$ at Site B).

Each of the dependent variables, mean density, mean depth, and $\mathrm{CV}$, was analyzed by analysis of covariance for each year of the study (SPSS MANOVA Procedure, SPSS 1986). Variables were log-transformed when necessary to reduce nonnormality of the data and eliminate heterogeneity of variances. Transformations equalized variances in all but 2 analyses. In these instances I proceeded with the analysis of covariance, but indicated statistical significance only if $\mathrm{p}$-values were less than significance levels of Cochran's test for homogeneity of variance (Underwood 1981).

Independent variables in the analyses differed among years, reflecting differences in sampling designs. In 1988, the factor was Date of Collection with the covariates being Current Speed, Wind Speed, Light, Water Temperature, and Salinity. In 1989, Current Direction (flood or ebb) was a factor, and the covariates were Current Speed and Wind Speed. Light, Water Temperature and Salinity were omitted as covariates because all but one sample were collected during darkness, and water temperature and salinity varied less than $1^{\circ} \mathrm{C}$ and 1 psu. In 1990, Current Direction and Light were 2-level factors, with Current Speed, Wind Speed and Stratification Index as covariates. Light was treated as a 2-level factor instead of a covariate in 1990 because measures of light level and the response of megalopae to light fell into 2 groups, each occurring within both levels of Current Direction.

\section{RESULTS}

\section{8 study}

Water temperature ranged from 14.5 to $16.8^{\circ} \mathrm{C}$ over the 5 sampling periods, but varied no more than $0.4{ }^{\circ} \mathrm{C}$ during the 4 sets on any date. Salinity remained nearly constant at 23.9 to 24.1 psu during sampling. Winds blew from the southeast on 21 October and southwest during the other 4 periods with maximum speeds of 4.1 to $6.1 \mathrm{~m} \mathrm{~s}^{-1}$.

Flood current speeds during sampling lat a depth of $105 \mathrm{~cm}$ below surface) ranged from 14.8 to $29.4 \mathrm{~cm} \mathrm{~s}^{-1}$, with a mean of $21.8 \mathrm{~cm} \mathrm{~s}^{-1}$ (Fig. 2). Because current speed was not measured for the
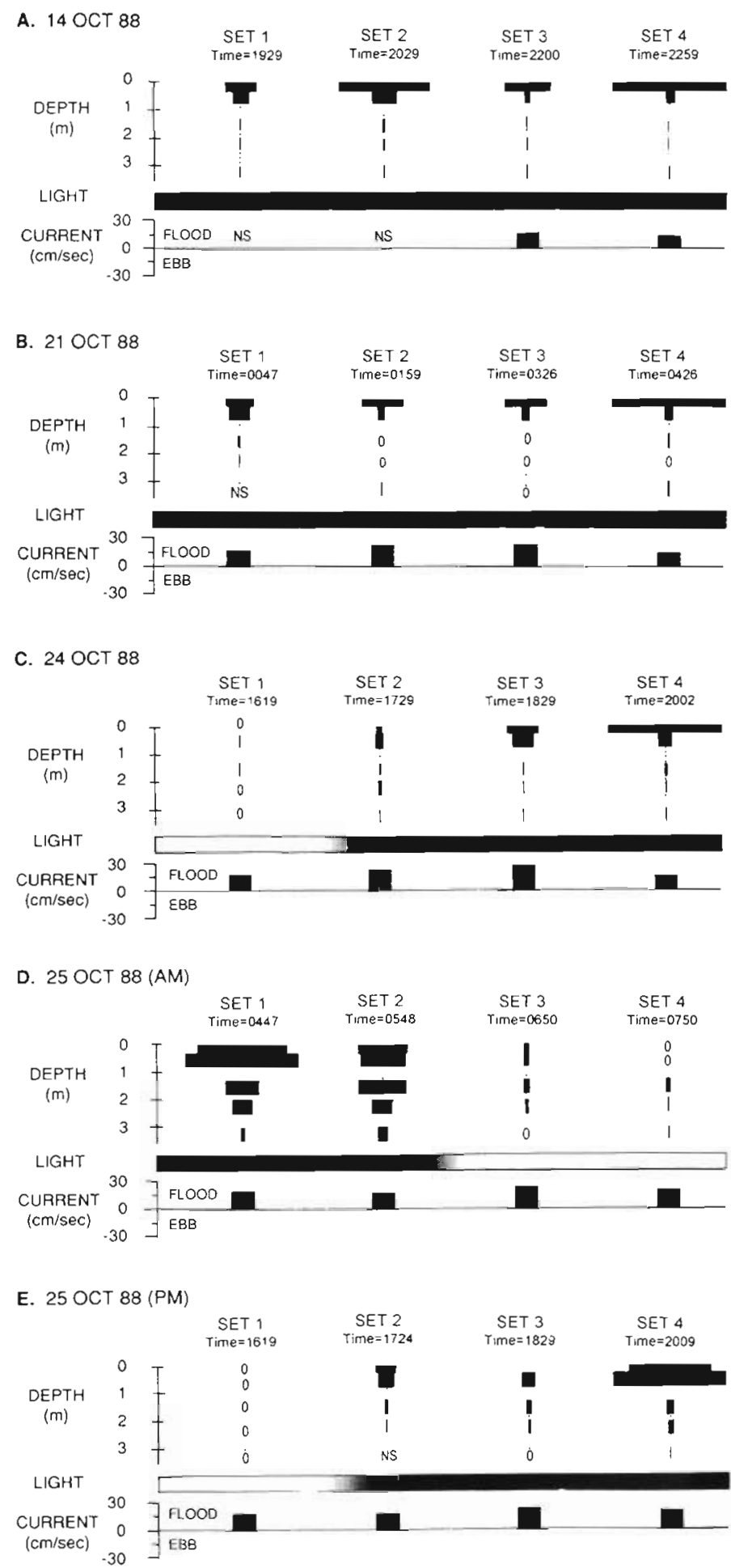

Fig. 2. Callinectes sapidus. Abundance of blue crab megalopae relative to depth strata, light and current speed at Site A in 1988. Depth strata sampled were: 0 to $30 \mathrm{~cm}, 30$ to $80 \mathrm{~cm}, 130$ to $180 \mathrm{~cm}$, 200 to $250 \mathrm{~cm}$, and 300 to $350 \mathrm{~cm}$ below surface. NS: no sample. Abundances are scaled to the maximum density in each series of 4 sets: (A) 82.3 ind $10 \mathrm{~m}^{-3}$, Set 4 , surface; (B) 13.0 ind. $10 \mathrm{~m}^{-3}$, Set 4 , surface; (C) 61.9 ind. $10 \mathrm{~m}^{-3}$, Set 4 , surface; (D) 6.5 ind. $10 \mathrm{~m}^{-3}$,

Set 1,30 to $80 \mathrm{~cm}$; (E) 20.1 ind. $10 \mathrm{~m}^{-3}$, Set 4,30 to $80 \mathrm{~cm}$ 
first 2 collections on 14 October, these were omitted from the analyses which included Current Speed as a covariate. Blue crab megalopae numbered 2323 individuals.

Megalopae were concentrated near the surface during nocturnal flood tides. On 14 and 21 October, when all samples were collected during darkness, megalopae were aggregated (distribution significantly different from random) with maximum densities in the upper $30 \mathrm{~cm}$ of the water column and a weighted mean

Table 1. Callinectes sapidus. Mean density (ind. $10 \mathrm{~m}^{-3}$ ) and weighted mean depth (m) of megalopae by date and set for 1988 collections. Degree of aggregation of megalopae is represented by the coefficient of variation (CV) and by comparison of the actual distribution with theoretical uniform and random distributions (ns, $\mathrm{p}>0.05 ; \cdot \mathrm{p}<0.05 ; \cdots p<0.01$ )

\begin{tabular}{|c|c|c|c|c|c|c|}
\hline Date & Set & $\begin{array}{c}\text { Mean } \\
\text { density }\end{array}$ & $\begin{array}{l}\text { Mean } \\
\text { depth }\end{array}$ & $\mathrm{CV}$ & Uniform & Random \\
\hline \multirow[t]{4}{*}{14 Oct } & 1 & 6.89 & 0.35 & 1.43 & $\cdots$ & $\because$ \\
\hline & 2 & 17.22 & 0.32 & 1.56 & $\cdots$ & $\cdots$ \\
\hline & 3 & 7.84 & 0.25 & 1.91 & . & $\cdots$ \\
\hline & 4 & 17.75 & 0.23 & 2.02 & $\cdots$ & $\cdots$ \\
\hline \multirow[t]{4}{*}{21 Oct } & 1 & 1.49 & 0.41 & 1.02 & . & . \\
\hline & 2 & 1.15 & 0.29 & 1.69 & $\cdots$ & $\cdots$ \\
\hline & 3 & 0.96 & 0.19 & 1.96 & .. & .. \\
\hline & 4 & 2.83 & 0.21 & 2.02 & $\cdots$ & $\cdots$ \\
\hline \multirow[t]{4}{*}{24 Oct } & 1 & 0.05 & 0.82 & 1.58 & ns & ns \\
\hline & 2 & 1.32 & 0.86 & 1.03 & $\cdots$ & $\cdot$ \\
\hline & 3 & 5.47 & 0.34 & 1.37 & $\cdots$ & $\cdots$ \\
\hline & 4 & 14.11 & 0.22 & 1.91 & $\cdots$ & $\cdots$ \\
\hline 25 Oct & 1 & 2.92 & 0.68 & 0.94 & $\cdots$ & .. \\
\hline \multirow[t]{3}{*}{ AM } & 2 & 1.95 & 1.07 & 0.53 & $\cdots$ & ns \\
\hline & 3 & 0.21 & 0.98 & 0.61 & ns & ns \\
\hline & 4 & 0.06 & 2.06 & 1.15 & $\mathrm{~ns}$ & ns \\
\hline $25 \mathrm{Oct}$ & 1 & 0.00 & & & & \\
\hline \multirow[t]{3}{*}{ PM } & 2 & 1.67 & 0.43 & 1.01 & $\cdots$ & ns \\
\hline & 3 & 0.83 & 0.91 & 1.46 & . & $\cdots$ \\
\hline & 4 & 7.44 & 0.47 & 1.26 & $\cdots$ & $\cdots$ \\
\hline
\end{tabular}

Table 2. Callinectes sapidus. Results of analysis of covariance for 1988 data. Error $\mathrm{df}=8$ for mean density; error $\mathrm{df}=7$ for mean depth and CV. ns, $p>0.05 ;$; $p<0.05 ;{ }^{\prime} " p<0.01 ; \cdots p<$ $0.001 .(+)$ positive relationship. (-) negative relationship

\begin{tabular}{lccc|}
\hline Source & Mean density & Mean depth & $\mathrm{CV}$ \\
\hline Date & $\mathrm{ns}$ & $\mathrm{ns}$ & $\mathrm{ns}$ \\
Covariates & $\cdot$ & $\mathrm{ns}$ & $\mathrm{ns}$ \\
Temperature & $\mathrm{ns}$ & $\mathrm{ns}$ & $\mathrm{ns}$ \\
Salinity & $\mathrm{ns}$ & $\mathrm{ns}$ & $\mathrm{ns}$ \\
Wind speed & $\mathrm{ns}$ & $\mathrm{ns}$ & $\mathrm{ns}$ \\
Light & $\cdots \cdot(-)$ & $\cdot(+)$ & $\mathrm{ns}$ \\
Current speed & $\mathrm{ns}$ & $\mathrm{ns}$ & $\mathrm{ns}$ \\
\hline
\end{tabular}

depth in the upper $41 \mathrm{~cm}$ (Fig. 2A, B). The degree of aggregation increased and the mean depth decreased from early to late flood (Table 1).

The other 3 flood-tide sampling periods encompassed crepuscular periods - dusk on 24 October and dawn and dusk on 25 October. Blue crab megalopae were concentrated near the surface during darkness, but during daylight and twilight, megalopae were generally less abundant, deeper, and more evenly distributed in the water column (Table 1, Fig. 2C to E). Whereas megalopae were significantly aggregated during darkness, their distributions did not differ significantly from random for most daylight or twilight collections (Table 1).

Date was not a significant factor for any of the dependent variables. Mean density and mean depth of megalopae varied significantly with Light, but not with the other covariates - Temperature, Salinity, Wind Speed and Current Speed. Light was negatively correlated with abundance of megalopae and positively correlated with their depth in the water column. The aggregation of megalopae (CV) did not vary significantly in relation to any of the covariates (Table 2).

Among the dependent variables, mean depth was negatively correlated with mean density ( $\mathrm{df}=18, \mathrm{r}=$ $-0.692, p<0.01)$ and $\mathrm{CV}(\mathrm{df}=17, \mathrm{r}=-0.574, \mathrm{p}<0.05)$; at night megalopae increased in abundance and aggregated near the surface. CV and mean density, however, were not significantly correlated with each other (df $=17, r=0.387, p>0.05)$.

\section{9 study}

Water temperature and salinity varied by less than $1^{\circ} \mathrm{C}\left(19.9\right.$ to $\left.20.8^{\circ} \mathrm{C}\right)$ and 1 psu $(19.0$ to $19.5 \mathrm{psu})$, respectively. Preliminary analyses indicated no significant effect of salinity or temperature, so these variables were omitted from the ANCOVA to increase the error degrees of freedom. Current speeds varied from 6.4 to $26.2 \mathrm{~cm} \mathrm{~s}^{-1}$; winds were generally from the southeast at speeds of 3.2 to $7.1 \mathrm{~m} \mathrm{~s}^{-1}$. A total of 513 blue crab megalopae was collected.

Blue crab megalopae exhibited a pattern during the dusk/night flood tide in the 1989 study similar to that observed in 1988. During early flood at dusk (Set 1), megalopal density was low and megalopae were distributed throughout the water column (Fig. 3, Table 3). The density of megalopae and their aggregation near the surface increased throughout the nocturnal flood tide (Sets 2 to 5), so that by late flood (Sets 4 and 5) megalopae were highly aggregated (CV > 1.4) with a weighted mean depth within $31 \mathrm{~cm}$ of the surface (Fig. 3, Table 3). In the last collection during flood (Set 5), the density of megalopae in the upper $30 \mathrm{~cm}$ 


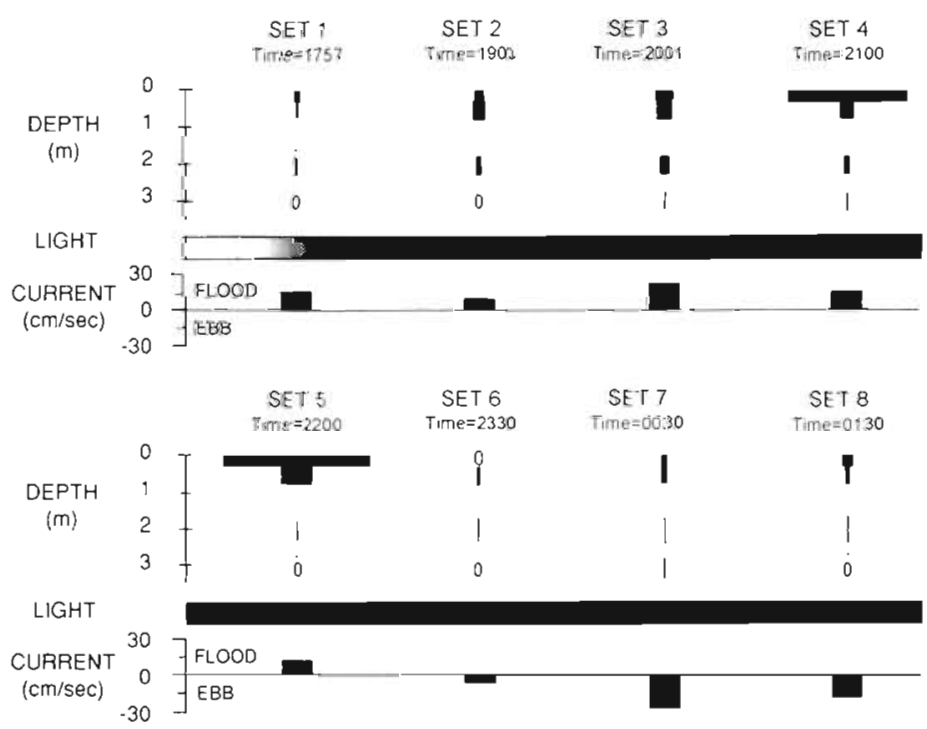

Fig. 3. Callinectes sapidus. Abundance of blue crab megalopae relative to depth strata, light and current speed at Site B during 16-17 October 1989. Depth strata sampled were 0 to 30, 30 to 80,180 to 230, and 280 to $330 \mathrm{~cm}$ below surface. Abundances are scaled to the maximum density of 27.9 ind. $10 \mathrm{~m}^{-3}$, Set 5 , surface density of megalopae dropped to 0.3 ind. $10 \mathrm{~m}^{-3}$ with no megalopae in the surface net. Mean densities remained low $(<0.9)$ for the remainder of the ebb, even though these were nighttime samples (Fig. 3, Table 3).

Megalopae were significantly $(>8 \times)$ more abundant during flood than during ebb (Table 4). Maximum densities were always in the upper 2 strata; thus, mean depth of megalopae did not differ significantly between flood $(0.47 \mathrm{~m})$ and ebb $(0.63 \mathrm{~m})$ sets. Aggregation of megalopae also did not differ significantly between flood and ebb collections. None of the dependent variables varied significantly with the covariates Wind Speed and Current Speed (Table 4).

As in 1988, mean density and mean depth of megalopae were inversely correlated $(\mathrm{df}=6$, $r=-0.729, p<0.05$ ); high abundance was only found near the surface. CV was not significantly correlated with mean depth $(\mathrm{df}=6$, $r=-0.470, p>0.05)$ or mean density $(\mathrm{df}=6$, $r=0.530, p>0.05)$.

\section{0 study}

was 27.9 ind. $10 \mathrm{~m}^{-3}$, with a mean density for the set of 8.8 ind. $10 \mathrm{~m}^{-3}$.

During the first sample of ebb tide (Set 6), approximately 30 min after the current began to ebb, the mean

Table 3. Callinectes sapidus. Mean density (ind $10 \mathrm{~m}^{-3}$ ) and weighted mean depth $(\mathrm{m})$ of megalopae by set for samples collected 16-17 October 1989. The degree of aggregation of megalopae is represented by the coefficient of variation (CV) and by comparison of the observed distribution with theoretical uniform and random distributions. ns, $\mathrm{p}>0.05 ;{ }^{\circ} \mathrm{p}<0.05$; $\cdots p<0.01$

\begin{tabular}{|cccccc|}
\hline Set & $\begin{array}{c}\text { Mean } \\
\text { density }\end{array}$ & $\begin{array}{c}\text { Mean } \\
\text { depth }\end{array}$ & CV & Uniform & Random \\
\hline 1 & 0.47 & 0.70 & 0.81 & $\cdots$ & ns \\
2 & 1.23 & 0.58 & 0.87 & $\cdots$ & ns \\
3 & 1.99 & 0.73 & 0.72 & $\cdots$ & ns \\
4 & 6.51 & 0.26 & 1.67 & $\cdots$ & $\cdots$ \\
5 & 8.78 & 0.31 & 1.48 & $\cdots$ & . \\
6 & 0.32 & 0.97 & 1.36 &. & ns \\
7 & 0.54 & 0.51 & 0.98 & $\cdots$ & ns \\
8 & 0.81 & 0.41 & 1.14 & $\cdots$ & $\cdot$ \\
\hline
\end{tabular}

Table 4. Results of analysis of covariance for 1989 data. Error $\mathrm{df}=4 . \mathrm{ns}, \mathrm{p}>0.05 ; \cdot \mathrm{p}<0.05$

\begin{tabular}{|lccc|}
\hline Source & Mean density & Mean depth & CV \\
\hline Current direction & $\cdot$ & ns & ns \\
Covariates & ns & ns & ns \\
Wind speed & ns & ns & ns \\
Current speed & ns & ns & ns \\
\hline
\end{tabular}

Current speeds ranged from 2.2 to $56.3 \mathrm{~cm} \mathrm{~s}^{-1}$ with means (depth averaged) of 42.5 to $53.5 \mathrm{~cm} \mathrm{~s}^{-1}$ (Figs. 4 \& 5). Water temperature varied between 21.9 and $23.3^{\circ} \mathrm{C}$ and salinity varied between 19.5 and $20.7 \mathrm{psu}$ (Fig. 4). The water column was generally well mixed, with the stratification index $\left(\Delta \sigma_{\mathrm{t}} / \mathrm{Z}\right)$ varying between 0.0026 and 0.0764 (Fig. 5). Maximum variation in $\sigma_{\mathrm{t}}$ over $1 \mathrm{~m}$ depth ranged from 0.028 to 0.378 and generally (15 of 25 sets) occurred in the upper $2 \mathrm{~m}$, usually during afternoon ebb tides (e.g. Sets 6 and 18). Winds were generally from the south at 2.2 to $6.4 \mathrm{~m} \mathrm{~s}^{-1}$. Blue crab megalopae numbered 2587 individuals.

During the $50 \mathrm{~h}$ sampling period, mean densities (per set) of blue crab megalopae varied from 0.06 to 8.02 ind. $10 \mathrm{~m}^{-3}$, mean depth ranged from 0.18 to $10.0 \mathrm{~m}$, and CV varied between 1.33 and 2.01 (Table 5).

As in 1988 and 1989, blue crab megalopae were most abundant during nocturnal flood tides in 1990. Megalopae were significantly more abundant during flood than ebb, with peak densities during early and midflood current stages (Figs. 4 \& 5; Tables $5 \& 6$ ). Although densities generally were higher at night, megalopae were sometimes abundant during daylight flood tides, but only near the bottom, causing Light and the Light $\times$ Current Direction interaction to be non-significant factors ( $d f=1, p>0.05$, Table 6 ). The covariates - Current Speed, Stratification and Wind Speed - were not significantly correlated with megalopal densities. 
Sets 1 to 10

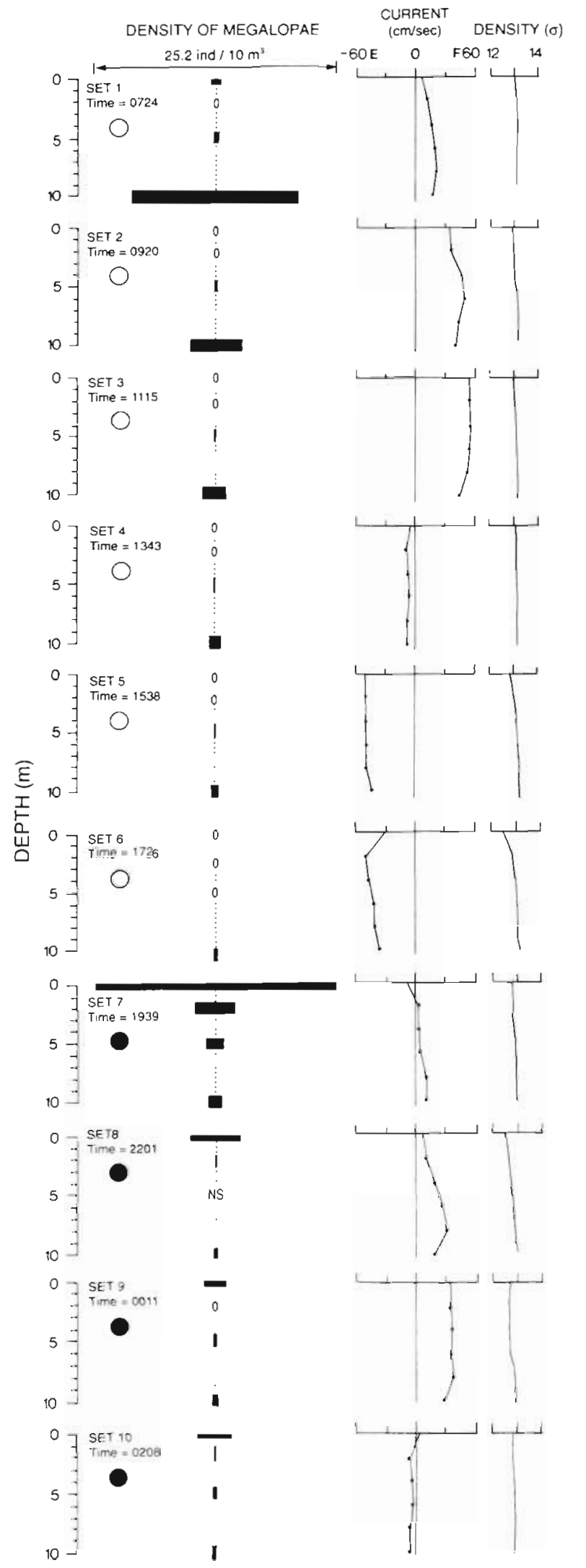

Sets 11 to 20

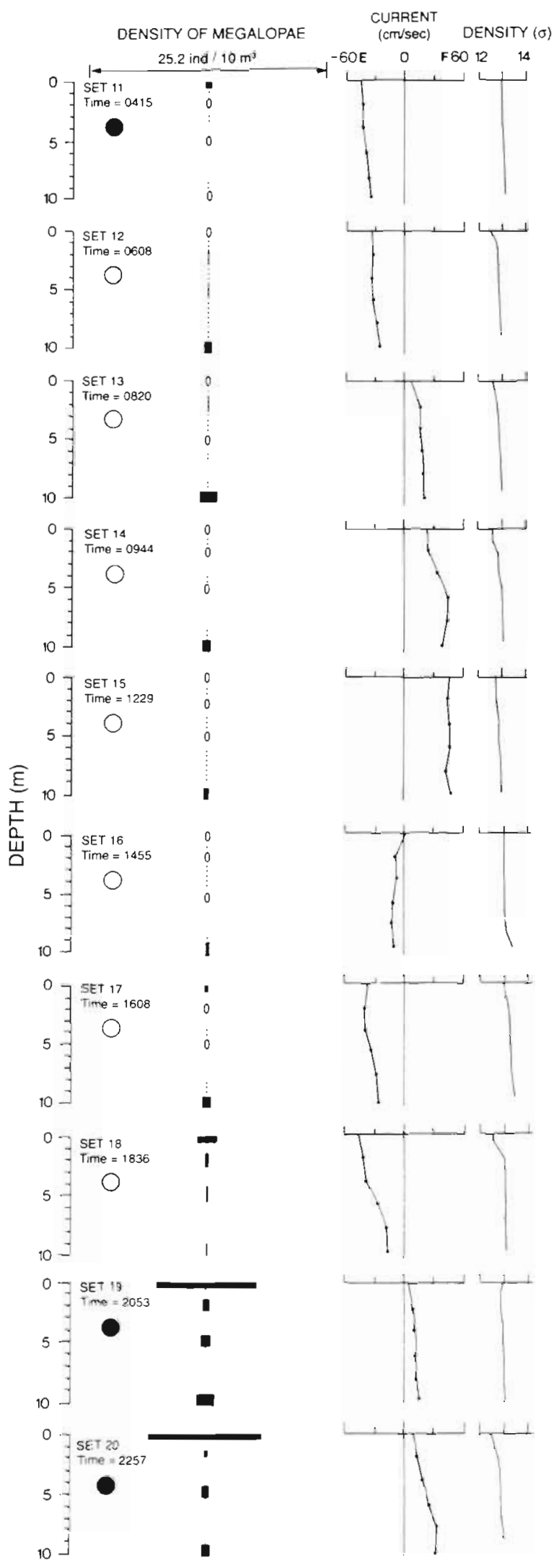




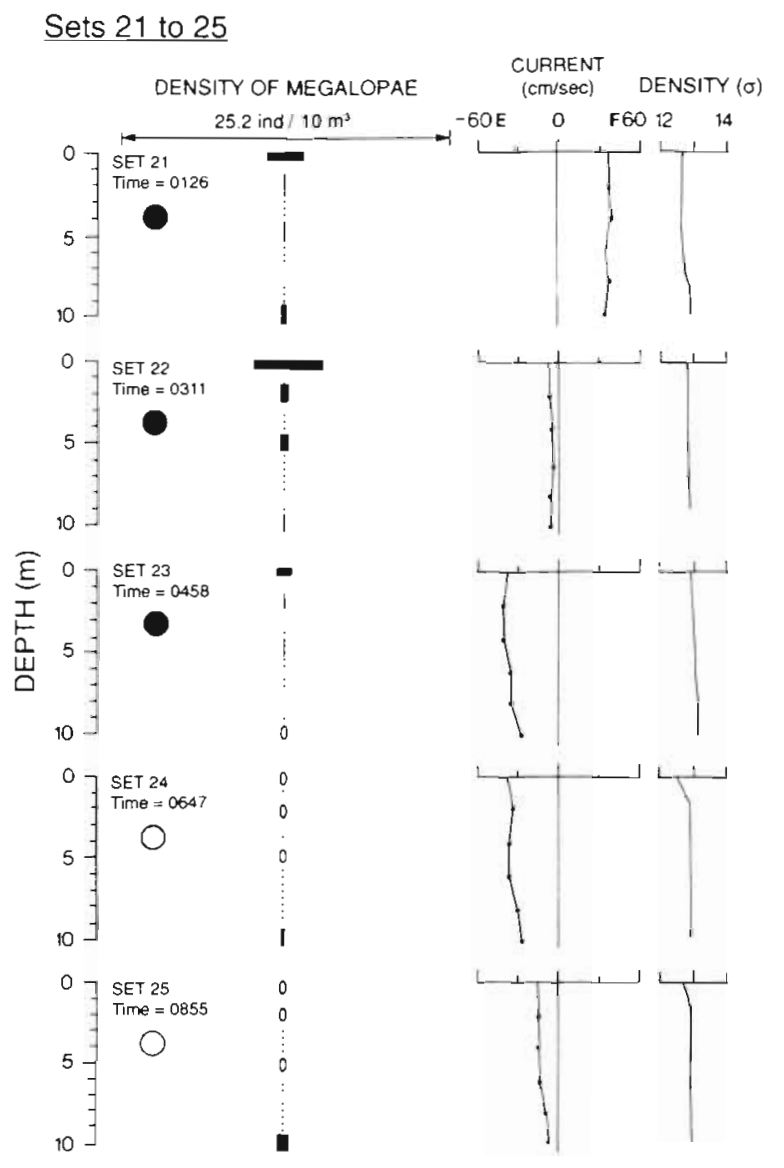

Fig. 4 (facing page and above). Callinectes sapidus. Data by set from Site C during 8-10 October 1990. (O) daytime; 10 night; $(\bigcirc)$ dawn or dusk. For each set - Left: abundance of blue crab megalopae by depth strata; abundances of megalopae are scaled to the maximum density of 25.2 ind. $10 \mathrm{~m}^{-3}$, Set 7, surface. Center: depth profile (surface, 2, 4, 6, 8, and $10 \mathrm{~m}$ ) of current direction ( $\mathrm{F}$ : flood, $\mathrm{E}$ : ebb) and speed. Right: depth profile of water density $\left(\sigma_{1}\right)$

The depth distribution of megalopae was significantly affected by light (Table 6). During daylight, megalopae remained near the bottom (mean depth between 8.8 and $10.0 \mathrm{~m}$ ). In contrast, at night megalopae were most concentrated at the surface with a mean depth within $2 \mathrm{~m}$ of the surface (Figs. 4 \& 5). Mean depth of megalopae was not affected by Current Direction, the Light $\times$ Current Direction interaction, or the covariates - Current Speed, Stratification or Wind Speed (Table 6).

Blue crab megalopae were significantly more aggregated during daylight than at night (Table 6). Megalopae occurred almost exclusively at the $10 \mathrm{~m}$ stratum during daylight; at night they occurred throughout the water column, though most abundant near the surface (Fig. 4, Table 5). Current Direction and the Light $x$ Current Direction interaction were not significant factors. Among covariates, CV was negatively correlated

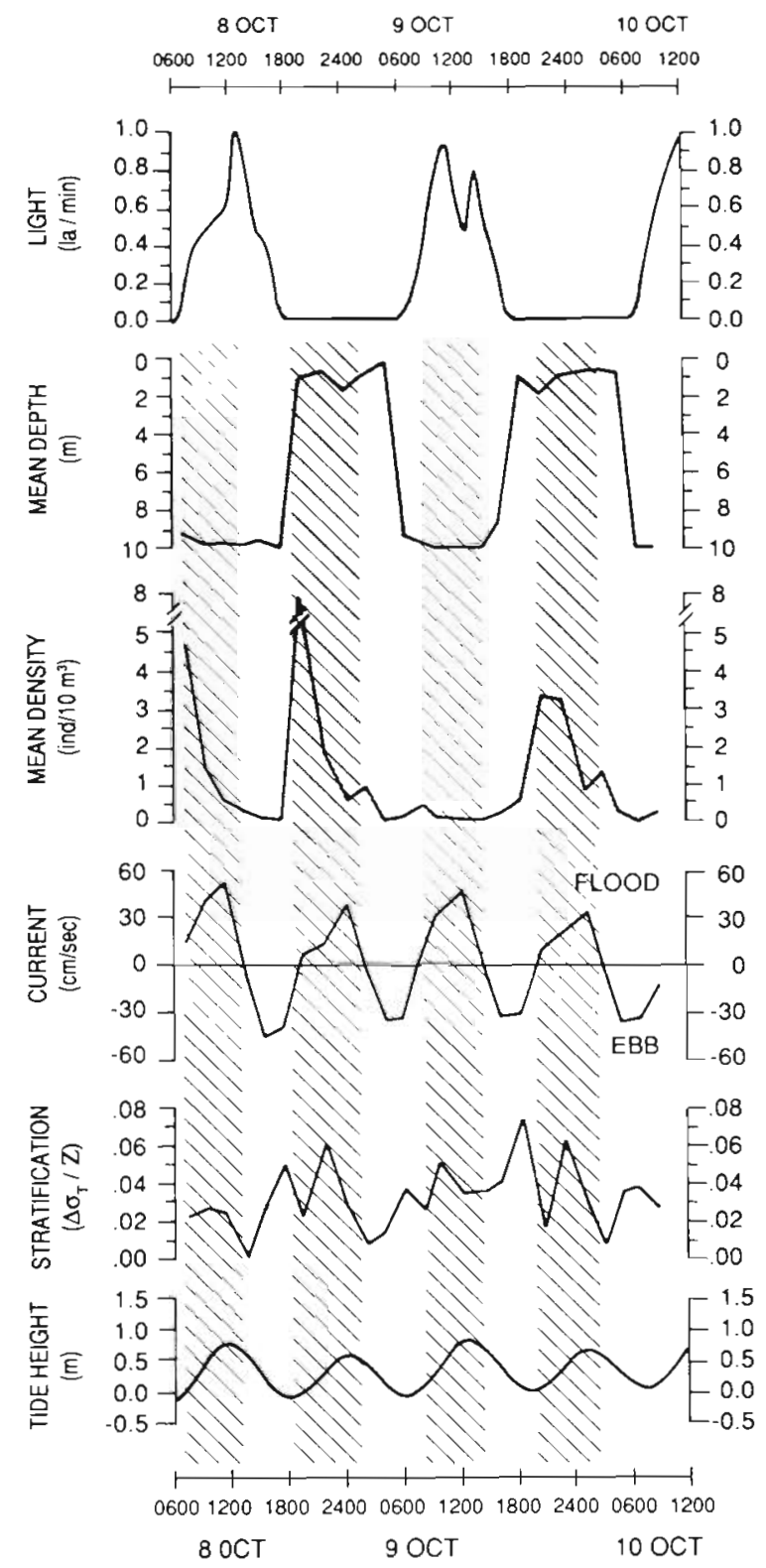

Fig. 5. Callinectes sapidus. Mean density and mean depth of megalopae with light, depth-averaged current speed, stratification index, and tidal height during 8-10 October 1990 Shading represents night and hatching indicates times of flood current

with Wind Speed but not Current Speed or Stratification (Table 6).

$\mathrm{CV}$ was negatively correlated with megalopal density ( $d f=23, r=-0.704, p<0.001)$ and positively correlated with mean depth of megalopae ( $\mathrm{df}=23, \mathrm{r}=0.484$, $p<0.05$ ); megalopae were most aggregated during the day when generally less abundant and concentrated at the deep stratum. Mean depth and mean density were not significantly correlated with each other $(\mathrm{df}=23, \mathrm{I}=$ $-0.392, p>0.05$ ). 
Table 5. Callinectes sapidus. Mean density (ind. $10 \mathrm{~m}^{-3}$ ) and weighted mean depth $(\mathrm{m})$ of megalopae by set for samples collected 8-10 October 1990. The degree of aggregation of megalopae is represented by the coefficient of variation and by comparison of the observed distribution with theoretical uniform and random distributions. ns: $p>0.05, \mathrm{p}<0.05$, $\cdots p<0.01$

\begin{tabular}{|c|c|c|c|c|c|}
\hline Set & $\begin{array}{c}\text { Mean } \\
\text { density }\end{array}$ & $\begin{array}{l}\text { Mean } \\
\text { depth }\end{array}$ & $C V$ & Uniform & Random \\
\hline 1 & 4.70 & 9.24 & 1.76 & $\cdots$ & $\cdots$ \\
\hline 2 & 1.49 & 9.81 & 1.90 & $\cdots$ & $\cdots$ \\
\hline 3 & 0.62 & 9.77 & 1.88 & $\cdots$ & $\cdot$ \\
\hline 4 & 0.28 & 9.83 & 1.91 & $\because$ & $\cdot$ \\
\hline 5 & 0.20 & 9.56 & 1.77 & $\cdots$ & ns \\
\hline 6 & 0.08 & 10.00 & 1.99 & $\cdots$ & $\mathrm{ns}$ \\
\hline 7 & 8.02 & 1.03 & 1.43 & $\cdots$ & $\cdots$ \\
\hline 8 & 1.80 & 0.65 & 1.55 & $\cdots$ & $\cdot$ \\
\hline 9 & 0.68 & 1.68 & 1.50 & $\cdots$ & $\cdot$ \\
\hline 10 & 1.06 & 0.93 & 1.62 & $\cdots$ & • \\
\hline 11 & 0.08 & 0.18 & 1.99 & $\because$ & ns \\
\hline 12 & 0.15 & 9.28 & 1.71 & $\cdots$ & ns \\
\hline 13 & 0.49 & 9.86 & 1.95 & $\cdots$ & $\cdot$ \\
\hline 14 & 0.17 & 10.00 & 2.00 & $\cdots$ & ns \\
\hline 15 & 0.08 & 10.00 & 2.01 & $\cdots$ & ns \\
\hline 16 & 0.07 & 10.00 & 2.00 & $\cdots$ & $\cdot$ \\
\hline 17 & 0.23 & 8.79 & 1.69 & $\because$ & ns \\
\hline 18 & 0.61 & 0.80 & 1.66 & $\cdots$ & $\cdot$ \\
\hline 19 & 3.62 & 1.91 & 1.33 & $\because$ & $\cdots$ \\
\hline 20 & 3.41 & 0.88 & 1.70 & $\because$ & $\cdots$ \\
\hline 21 & 0.79 & 0.55 & 1.84 & $\cdots$ & $\cdots$ \\
\hline 22 & 1.61 & 0.57 & 1.72 & $\because$ & $\cdots$ \\
\hline 23 & 0.29 & 0.59 & 1.68 & $\cdots$ & $\cdot$ \\
\hline 24 & 0.06 & 10.00 & 2.00 & $\cdots$ & ns \\
\hline 25 & 0.26 & 10.00 & 2.00 & $\cdots$ & $\cdot$ \\
\hline
\end{tabular}

Table 6. Callinectes sapidus. Results of analysis of covariance for 1990 data. Error df $=18$. ns, $p>0.055^{\circ} \mathrm{p}<0.05$; $\cdots p<0.01 ; \cdots p<0.001$. (-) negative relationship

\begin{tabular}{|lccc|}
\hline Source & Mean density & Mean depth & CV \\
\hline Light & ns & $\ldots$ & $\ldots$ \\
Current direction & $\cdot$ & ns & ns \\
Light $\times$ Curr. dir. & ns & ns & ns \\
Covariates & $\cdot$ & ns & ns \\
Wind speed & ns & ns & $\cdot(-)$ \\
Current speed & ns & ns & ns \\
Stratification & $n s$ & ns & ns \\
\hline
\end{tabular}

\section{DISCUSSION}

The blue crab megalopa is a transitional stage in a complex life cycle (sensu Roughgarden et al. 1988) transitional in both morphology and behavior between the planktonic larval stages in coastal waters and the benthic juvenile stages in estuaries. A critical facet of this transition is the ability to immigrate to estuaries against the net seaward flow of estuarine waters. Reporting laboratory studies of blue crab zoeae and megalopae, Sulkin \& Van Heukelem (1986) stated: 'There are profound changes in behavior at the megalopa stage which result in a depth regulatory mechanism of high precision. This phenomenon, in combination with appropriate locomotor rhythms, could provide for transport into the estuary based both on net non-tidal flow and on tidal flow.' In the York River, blue crab megalopae displayed abundance variation and depth regulation in relation to light and current direction which should enable them to reach estuarine juvenile nurseries rapidly while concurrently reducing their susceptibility to visual predators in the plankton.

\section{Field distributions: response to light}

During both years (1988 and 1990) that the effect of light on the abundance and depth distribution of megalopae was examined, megalopae were significantly lower in the water column (usually near the bottom) during daylight than at night. This was particularly evident during 1990 when megalopae were most concentrated at the surface during darkness or at the deepest stratum (10 m) during day.

The effect of light on their abundance and aggregation was mixed, however, because of the different depths of sites occupied. At the shallow site (1988), most megalopae left the water column during daylight and likely were associated with the substrate; thus, their abundance in the water column also differed significantly between day and night collections. At the deep station (1990), megalopae were occasionally abundant, aggregated near the bottom ( $10 \mathrm{~m})$ during daylight. For this reason, mean densities did not differ significantly between day and night collections, but megalopae were more aggregated during day.

Reduced capture rates of megalopae in illuminated waters compared to dimly-lit waters raises the possibility of net avoidance. Blue crab megalopae are relatively strong swimmers compared to most invertebrate larvae (Luckenbach \& Orth 1992). The nets used in this study were large and coarse enough to allow mean filtration efficiencies of approximately $90 \%$ (Olmi 1993). While net avoidance cannot be completely dismissed, it is unlikely that the observed distributions of megalopae resulted from net avoidance, especially since high densities of megalopae have been collected with similar gear from the offshore neuston during daylight (Johnson 1982, Maris 1986, author's pers. obs.).

Blue crab zoeae exhibit positive phototaxis in the laboratory (Sulkin et al. 1979, 1980), but the light response of megalopae has not been characterized. Tankersley \& Forward (in press) observed that blue 
crab megalopae in the laboratory were more active during the day phase than at night, a result that contrasts most field observations, and concluded that observed distributions in the field were not the result of endogenous rhythms. Although in situ light levels were not measured in the present study, the presence of megalopae deep in the water column during daylight, throughout the water column at twilight, and at the surface at night suggests that megalopae adjust their depth to avoid light intensities above some threshold level, as do larvae of Rithropanopeus harrisii (Forward \& Cronin 1980, Forward et al, 1984). Movement between surface and bottom waters during twilight was evident in the 1988 data (e.g. Fig. 2B, C, D); although apparent in Set 7 , temporal resolution during 1990 may have been too coarse to observe this transition during each twilight period.

Depth distributions observed in this study agree with those of Mense \& Wenner (1989) who also found megalopae more abundant near the surface at night and near the bottom during the day in South Carolina estuaries. In other studies, however, the depth distribution of megalopae has not been proven to be lightregulated, though peak abundances generally occur at night (Epifanio et al. 1984, Brookins \& Epifanio 1985 , Little \& Epifanio 1991). In coastal waters off Chesapeake Bay, megalopae are concentrated in the neuston during daylight (Johnson 1982, Maris 1986, author's pers. obs.). Thus, it appears that activity of megalopae (and therefore, their abundance in the water column) is inhibited by light under estuarine conditions but not in offshore waters. Such behavior is consistent with Morgan's (1987) hypothesis that predation pressure is greater within estuaries than in coastal waters.

Although diurnal vertical migration may effect selective tidal stream transport in diurnal tides (Hill 1991), such behavior in the semi-diurnal tides of northwest Atlantic Coast estuaries would not efficiently transport megalopae up estuaries because megalopae would occupy surface waters during both flood and ebb. Thus, vertical migration in response to light does not explain the transport of blue crab megalopae up estuaries.

\section{Field distributions: response to tides}

Blue crab megalopae were significantly more abundant in the water column during flood than ebb tides, suggesting a net flux of megalopae up the estuary. Observing a similar pattern, Epifanio et al. (1984) suggested that megalopae dropped out of the water column prior to or during ebb and ascended from the bottom during flood (selective tidal stream transport). If megalopae are migrating between the bottom and the water column in response to the tidal cycle, then a difference in the depth distribution of megalopae between flood and ebb would be expected. Previous field studies, however, have not detected such a migration (Epifanio et al. 1984, Brookins \& Epifanio 1985, Maris 1986, Olmi 1986, Little \& Epifanio 1991).

I sampled 4 or 5 depth strata and also did not observe a significant change in the depth distribution of megalopae between flood and ebb. I suggest that most megalopae rapidly drop out of the water column prior to ebb and ascend during flood. Whether on flood or ebb, megalopae in the water column are distributed as a function of their response to light.

Blue crab megalopae exhibit a tidal periodicity in their abundance that should result in movement up the estuary. This behavior could be endogenous or stimulated by cues in the environment. Megalopae are sensitive to pressure change and respond to increasing pressure by raising their level of activity which, in concert with negative geotaxis, results in upward movement (Naylor \& Isaac 1973, Sulkin \& Van Heukelem 1982). Increasing salinity may also stimulate activity in larval crustaceans (Sulkin 1984).

Megalopae in contact with the bottom could sense tidal transitions by changes in pressure and water characteristics (e.g. salinity) during passage of the tidal wave. Increasing salinity and pressure during flood would stimulate movement into the water column. Megalopae descend by passive sinking, at a rate of $1.8 \pm 0.55 \mathrm{~cm} \mathrm{~s}^{-1}$ in the laboratory (Sulkin \& Van Heukelem 1982)

Frequent contact with the bottom and regular exposure to these stimuli could entrain a circatidal rhythm of activity. Cronin \& Forward (1983) reported that larvae of Rhithropanopeus harrisii seemed strongly predisposed to express tidal rhythms, and that larvae hatched from crabs of a strongly tidal estuary have circatidal vertical migrations. In a recent laboratory study, Uca sp. megalopae exhibited an endogenous tidal activity rhythm, but blue crab megalopae did not (Tankersley \& Forward in press). In addition, DeVries et al. (in press) noted a relationship between the abundance of blue crab megalopae in the water column and the rate of increase of salinity, but not pressure. Tidal activity rhythms related to exogenous cues have also been observed in postlarvae of penaeid shrimps (Hughes 1972, Mathews et al. 1991) and some fishes (Weinstein et al. 1980, Boehlert \& Mundy 1988).

I did not detect a relationship between megalopal abundance and salinity or temperature. Changing pressure would be a more conservative cue to stimulate upward movement, and other water characteristics may also be important. Also, these cues likely covary during flood and ebb. If there is not an endogenous rhythm to the tidal activity pattern of blue crab 
megalopae, then the cue(s) for descent out of the water column prior to ebb remain in question.

Finally, though the Light $\times$ Current Direction interaction term was not significant for each of the independent variables in 1990, there appeared to be an interaction between light and tide (flood or ebb) in their effect on megalopal behavior. Megalopae were not abundant during ebb. During night flood, megalopae were abundant and near the surface; while during day flood, they were concentrated near the bottom and their abundance was variable.

\section{Field distributions: response to other factors}

The presence and depth of a pycnocline may affect the depth distribution of invertebrate larvae (Tremblay \& Sinclair 1990, Boudreau et al. 1992). In the present study, the water column was generally well mixed at the deep site, and the abundance and depth distribution of megalopae was not related to changes in water column density. Water column temperature and salinity were not profiled at the shallow sites but stratification was not expected, given the minimal variation in temperature and salinity during sampling.

Johnson $(1982,1985)$ noted a shift in the depth distribution of blue crab megalopae related to the presence or absence of a pycnocline along a transect from oligohaline waters of the upper York River to coastal waters off the mouth of Chesapeake Bay. The relationship between depth distribution of megalopae and a pycnocline may not be causal, however; these data may simply reflect the neustonic distribution of megalopae offshore (pycnocline) versus their vertical migratory behavior in estuaries (no pycnocline).

Turbulent mixing during periods of rapid currents or high wind stress may affect the abundance, depth distribution and aggregation of larvae (deWolf 1974 , Heath et al. 1988). The depth distribution of larvae of the mud crab Rhithropanopeus harrisii in the Newport River, North Carolina, exhibited a $6.2 \mathrm{~h}$ periodicity; larvae were highest in the water column during maximurn currents (Cronin 1982, Cronin \& Forward 1982). This pattern was interpreted as an active response of larvae to mixing events in the water column rather than passive redistribution of larvae by turbulent flow (Cronin \& Forward 1986). In the present study, current speed was not significantly correlated with density, mean depth, or aggregation of blue crab megalopae. Maximum densities occurred during early or late flood. not during maximum currents, and never during ebb. Wind stress also was not correlated with megalopal density or mean depth, and in only one instance was wind stress correlated with the degree of aggregation (1990). Thus, it appears that the vertical distribution of blue crab megalopae in the York River was determined by their combined response to light and current direction, and not to water temperature, salinity, or passive redistribution from turbulent mixing

\section{Conceptual model}

From the collective evidence in this and other studies (cited herein) emerges a conceptual model of the vertical distribution of blue crab megalopae in estuaries (Fig. 6). Most megalopae remain on the bottom during ebb. As the tidal wave passes and flood currents begin, increasing hydrostatic pressure and a change in water characteristics stimulates megalopal activity, resulting in movement of megalopae from the substratum into the water column. Prior to ebb, most megalopae descend from the water column by passive sinking, remaining on the bottom until the next flood. This circatidal activity pattern - active during flood and inactive during ebo - may have an endogenous component, though a recent laboratory study suggests otherwise (Tankersley \& Forward in press).

Ascent of megalopae into the water column is limited by light intensity. At night, megalopae move to the surface, concentrating there during flood tides. During daylight, however, megalopae appear to move up in the water column until encountering a threshold light level, which reduces their activity and concentrates them lower in the water column. In shallow water, this
DAY

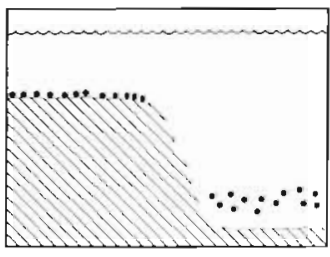

NIGHT

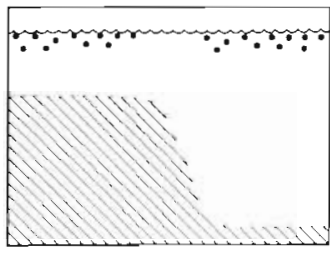

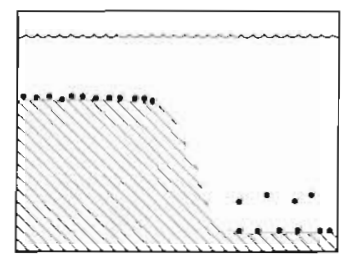

$E B B$

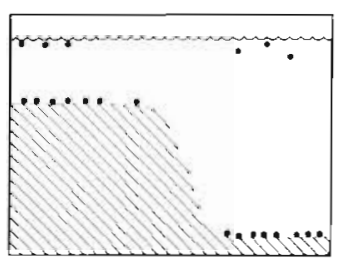

Fig. 6. Callinectes sapidus. Conceptual. model of the depth distribution of blue crab megalopae in relation to light (day or night) and current direction (flood or ebb). Relative abundance and depth distribution of megalopae (indicated by dots) are shown for shallow and deep water locations in each light by tide combination. Direction of tidal currents is normal to the page 
threshold light level may extend to the bottom such that megalopae remain inactive during the daylight flood. Megalopae may be found throughout the water column during twilight, moving between surface and bottom waters, with the direction of movement determined by whether light is increasing (dawn) or decreasing (dusk).

This model is appropriate for megalopae in estuaries, but not for megalopae in coastal waters, where they are mostly neustonic. There appears to be a change in the behavior of blue crab megalopae in the vicinity of inlets, as suggested by Boehlert \& Mundy (1988) for finfish. They suggested that multiple cues in the estuarine environment (e.g. reduced salinity, increased tidal turbulence, estuarine 'odors') may trigger such a change in behavior.

\section{Effect of depth distribution on transport}

Net non-tidal inflow of bottom water into estuaries with 2-layered flow has been regarded as a probable mechanism for transport into estuaries since the studies of Tagatz (1968) and Sandifer (1973, 1975). Epifanio (1988), however, noted that bottom drift into Delaware Bay was extremely slow, and suggested that megalopae may augment their landward transport by tidally timed, vertical migration.

I utilized NOAA tidal current tables for 1990 (NOS 1989), to estimate time of transport from the Chesapeake Bay mouth to Gloucester Point in the York River for megalopae in bottom water and for megalopae which behaved as according to this model.

Surface and bottom current predictions were used for the following 4 stations: Bay Mouth (Cape Henry Light, NOAA Station 4446), Lower Bay (Chesapeake Channel Buoy 11, NOAA Station 4501\}, York River Entrance Channel (NOAA Station 5311), and Lower York River (Tue Marshes Light, NOAA Station 5326). Assuming sinusoidal oscillations, the distance traveled during half a tidal period was calculated by integrating the area under (flood) or over (ebb) the curve, the amplitude and duration of which were taken from the tidal current tables (E. P. Ruzecki pers. comm.). Current speeds between stations were approximated by interpolation, and Tue Marshes Light currents were used for the remainder of the York River up to Gloucester Point. I back-calculated transport starting with megalopae collected during the 1990 field study at Site $C$ (Gloucester Point) during mid-flood on the night of 9 October (Set 20).

Megalopae that resided continuously in bottom water required 13 tidal cycles to travel from the Bay Mouth to Gloucester Point. Those megalopae that were collected the night of 9 October 1990 at Glouces- ter Point would have entered the Bay Mouth during flood on the morning of 3 October.

To estimate transport time of vertically migrating megalopae, I assumed that megalopae were on the bottom during ebb and in the water column during flood. During flood, megalopae were near the surface at night (18:00 to $07: 00 \mathrm{~h}$ ) and near the bottom during day (07:00 to 18:00 h). These megalopae required 8 tidal cycles to reach Gloucester Point having entered the Bay mouth during mid-flood on the morning of 6 October $(7$ flood tides would have accomplished this transport had the megalopae started at the Bay mouth during early flood on 6 October).

These transport times are approximate and represent only one set of tidal current conditions; however, they do provide an estimate of the time required for megalopae to traverse $56 \mathrm{~km}$ from the Bay mouth into the York River, a primary tributary of lower Chesapeake Bay. These calculations suggest that megalopae which behave as suggested by this model would reach Gloucester Point in 3 to $3.5 \mathrm{~d}$ compared to $6.5 \mathrm{~d}$ for megalopae remaining near the bottom and relying on residual non-tidal circulation.

\section{CONCLUSIONS}

Patterns of abundance and vertical distribution of blue crab megalopae in the York River strongly suggest that megalopae are vertically migrating: moving between the bottom during ebb and the water column during flood. The degree of upward movement is light limited; megalopae ascend to the surface at night, but remain on the bottom (shallow water) or deep in the water column during day flood

While the abundance and vertical distribution of megalopae in the York River was not related to temperature, salinity, stratification, current speed or wind speed, it is reasonable to assume that some environmental cue or combination of cues is regularly triggering tidal migratory behavior or entraining an endogenous tidal rhythm in megalopae. The transition in megalopal behavior from offshore (neustonic) to estuarine (vertically migrating and light avoiding) environments likely is triggered by cues in the estuarine environment. Clarification of the roles of such cues in the behavior of blue crab megalopae should be an interesting area of research

Regardless of the cues, the transition to tidally timed, vertical migration clearly is adaptive for transport up estuaries. Megalopae which behave according to the conceptual model presented here exhibited a net flux up the estuary and reduced by nearly half the time required to reach nursery areas in the York River, compared to transport in residual bottom water inflow. 
As blue crab megalopae migrate up the estuary and reach nursery areas, they are physiologically approaching metamorphosis to the juvenile stage (Lipcius et al. 1990, Metcalf \& Lipcius 1992). Rapid tidal transport of megalopae allows greater distribution of megalopae into nursery areas prior to metamorphosis and, presumably, reduced risk of mortality to estuarine predators along the way.

Acknowledgements. Special thanks to Jacques van Montfrans for his encouragement, invaluable assistance in field sampling, and review of this paper. I appreciate the help of all those who participated in the field sampling, especially $S$. Mauger, J. McGovern and P. Sadler. Also, thanks to the VIMS Vessel Operations staff. E. Ruzecki provided helpful advice on calculating transport times. R. Lipcius, C. Epifanio, M. Luckenbach. E. Ruzecki, and 3 anonymous reviewers provided many useful comments on an earlier draft of this paper. Financial assistance was provided by the W. A. Van Engel Fellowship, the Commonwealth of Virginia, and Awards NA90AA-D-SG042 and NA90AA-D-SG045 from the National Oceanographic and Atmospheric Administration to the Virginia Sea Grant College Program. This is contribution No. 1855 from the School of Marine Science, Virginia Institute of Marine Science, The College of William and Mary.

\section{LITERATURE CITED}

Boehlert, G. W., Mundy, B. C. (1988). Roles of behavioral and physical factors in larval and juvenile fish recruitment to nursery areas. Am. Fish. Soc. Symp. 3: 51-67

Boicourt, W. C. (1981). Circulation in the Chesapeake Bay entrance region: estuary-shelf interaction. In: Campbell J. W., Thomas, J. P. (eds.) Chesapeake Bay Plume Study, 1980. NASA Conf. Publ. 2188 (NOAA/NEMP II, 81 ABCDFG 0042), Washington, DC, p. 61-78

Boicourt, W. C. (1982). Estuarine larval retention mechanisms on two scales. In: Kennedy, V (ed.) Estuarine comparisons. Academic Press, New York, p. 445-457

Boudreau, B., Simard, Y., Bourget, E. (1992). Influence of a thermocline on vertical distribution and settlement of post-larvae of the American lobster Homarus americanus Milne-Edwards. J. exp. mar. Biol. Ecol. 162: 35-49

Bousfield, E. L. (1955). Ecological control of the occurrence of barnacles in the Miramichi estuary. Nat. Mus. Can. Bull. 137

Brookins, K. G., Epifanio C. E. (1985). Abundance of brachyuran larvae in a small inlet over six consecutive tidal cycles. Estuaries 8: 60-67

Bumpus, D. F. (1973). A description of the circulation on the continental shelf of the east coast of the United States. Prog. Oceanogr. 6: 111-157

Cronin, T W. (1982). Estuarine retention of the larvae of the crab Rhithropanopeus harrisii. Estuar. coast. Shelf Sci. 15: $207-220$

Cronin, T W., Forward, R. B. Jr (1982). Tidally timed behavior: effects on larval distributions in estuaries. In: Kennedy, V. (ed.) Estuarine comparisons. Academic Press, New York, p. 505-520

Cronin, T. W., Forward, R. B. Jr (1983). Vertical migration rhythms of newly hatched larvae of the estuarine crab, Rhithropanopeus harrisii. Biol. Bull. 165: 139-153

Cronin, T. W., Forward, R. B. Jr (1986). Vertical migration cycles of crab larvae and their role in larval dispersal. Bull. mar. Sci. 39: 257-268
DeVries, M. C., Tankersley, R. A., Forward, R. B. Jr, KirbySmith, W. W. Luettich, R. A. Jr (in press). The abundance of estuarine crab larvae is associated with tidal hydrologic variables. Mar. Biol.

deWolf, P. (1974). On the retention of marine larvae in estuaries. Thalassia jugosl. 10: 415-424

Dittel, A. I., Epifanio, C. E. (1982). Seasonal abundance and vertical distribution of crab larvae in Delaware Bay. Estuaries 5: 197-202

Dudley, D. L., Judy, M. H. (1971). Occurrence of larval, juvenile and mature crabs in the vicinity of Beaufort Inlet, North Carolina. NOAA, Tech. Rep. NMFS, SSRF 637: 1-10

Epifanio, C. E. (1988). Transport of invertebrate larvae between estuaries and the continental shelf. Am. Fish. Soc. Symp. 3: 104-114

Epifanio, C. E., Masse, A. K., Garvine, R. W. (1989). Transport of blue crab larvae by surface currents off Delaware Bay, USA. Mar. Ecol. Prog. Ser. 54: 35-41

Epifanio, C. E., Valenti, C. C., Pembroke, A. E. (1984). Dispersal and recruitment of blue crab larvae in the Delaware Bay. Estuar. coast. Shelf Sci. 18: 1-12

Fortier, L., Leggett, W. C. (1983). Vertical migrations and transport of larval fish in a partially mixed estuary. Can. J. Fish. Aquat. Sci. 40: 1543-1555

Forward, R. B. Jr (1985). Behavioral responses of larvae of the crab Rhithropanopeus harrisii (Brachyura: Xanthidae) during diel migration. Mar. Biol. 90: 9-18

Forward, R. B. Jr, Cronin, T W. (1980). Tidal rhythms of activity and phototaxis of an estuarine crab larva. Biol. Bull. 158: $295-303$

Forward, R. B. Jr, Cronin, T W., Stearns, D. E. (1984). Control of diel vertical migration: photoresponses of a larval crustacean. Limnol Oceanogr. 29: 146-154

Goodrich, D. M. (1988). On meteorologically induced flushing in three U. S. east coast estuaries. Estuar. coast. Shelf Sci. 26: $111-121$

Goodrich, D. M., van Montfrans, J., Orth, R. J. (1989). Blue crab megalopal influx to Chesapeake Bay: evidence for a wind-driven mechanism. Estuar. coast. Shelf Sci. 29: $247-260$

Haas, L. W. (1977). The effect of the spring-neap tidal cycle on the vertical salinity structure of the James, York, and Rappahannock Rivers, Virginia, U.S.A. Estuar. coast. mar. Sci. 5: 485-496

Heath, M. R., Henderson, E. W., Baird, D. L. (1988). Vertical distribution of herring larvae in relation to physical mixing and illumination. Mar. Ecol. Prog. Ser. 47: 211-228

Hill, A. E. (1.991). Vertical migration in tidal currents. Mar. Ecol. Prog. Ser. 75: 39-54

Hughes, D. A. (1972). On the endogenous control of tide-associated displacements of pink shrimp, Penaeus duorarum Burkenroad. Biol. Bull. 142: 271-280

Johnson, D. F. (1982). A comparison of recruitment strategies among brachyuran crustacean megalopae of the York River, lower Chesapeake Bay and adjacent shelf waters. Ph.D. dissertation, Old Dominion Univ., Norfolk, VA

Johnson, D. F. (1985). The distribution of brachyuran crustacean megalopae in the waters of the York River, lower Chesapeake Bay and adjacent shelf: implications for recruitment. Estuar. coast. Shelf Sci. 20: 693-705

Johnson, D. R. (1985). Wind-forced dispersion of blue crab larvae in the Middle Atlantic Bight. Cont. Shelf Res. 4: $1-14$

Johnson, D. R., Hester, B. S., McConaugha, J. R. (1984). Studies of a wind mechanism influencing the recruitment of blue crabs in the Middle Atlantic Bight. Cont. Shelf Res. 3: $425-4.37$ 
Laprise, R., Dodson, J. J. (1989). Ontogeny and importance of tidal vertical migrations in the retention of larval smelt Osmerus mordax in a well-mixed estuary. Mar. Ecol. Prog. Ser. 55: 101-111

Lipcius, R. N., Olmi, E. J. III, van Montfrans, J. (1990). Planktonic availability, molt stage and settlement of blue crab postlarvae. Mar. Ecol. Prog. Ser. 58: 235-242

Little, K. T., Epifanio, C. E. (1991). Mechanism for the reinvasion of an estuary by two species of brachyuran megalopae. Mar. Ecol. Prog. Ser. 68: 235-242

Luckenbach, M. W., Orth, R. W. (1992). Swimming velocities and behavior of blue crab (Callinectes sapidus Rathbun) megalopae in still and flowing water. Estuaries 15 186-192

Maris, R C. (1986). Patterns of diurnal vertical distribution and dispersal-recruitment mechanisms of decapod crustacean larvae and postlarvae in the Chesapeake Bay, Virginia and adjacent offshore waters. Ph.D. dissertation, Old Dominion Univ, Norfolk, VA

Mathews, T. R., Schroeder, W. W., Stearns, D. E. (1991). Endogenous rhythm, light and salinity effects on postlarval brown shrimp Penaeus aztecus Ives recruitment to estuaries. J. exp. mar. Biol. Ecol. 154: 177-189

McCleave, J. D., Bedaux, J. J. M., Doucet, P. G., Jager, J. C., Jong, J. T L., van der Steen, W. J., Voorzanger, B. (1987). Statistical methods for analysis of plankton and nekton distribution, with application to selective tidal stream transport of juvenile American eels (Anguilla rostrata) J. Cons. int. Explor. Mer 44: 90-103

McConaugha, J. R. (1988). Export and reinvasion of larvae as regulators of estuarine decapod populations. Am. Fish. Soc. Symp. 3: 90-103

McConaugha, J. R., Johnson, D. F., Provenzano, A. J., Maris, R. C. (1983). Seasonal distribution of larvae of Callinectes sapidus (Crustacea: Decapoda) in the waters adjacent to Chesapeake Bay. J. crust. Biol. 3: 582-591

Mense, D. J., Wenner, E. L. (1989). Distribution and abundance of early life history stages of the blue crab, Callinectes sapidus, in tidal marsh creeks near Charleston, S.C. Estuaries 12: 157-168

Meredith, W. H. (1982). The dynamics of zooplankton and micronekton community structure across a salt marshestuarine waters interface of lower Delaware Bay. Ph.D. dissertation, Univ. Delaware, Newark

Metcalf, K. S., Lipcius, R. N. (1992). Relationship of habitat and spatial scale with physiological state and settlement of blue crab postlarvae in Chesapeake Bay. Mar. Ecol. Prog. Ser. 82: $143-150$

Morgan, S. (1987). Morphological and behavioral antipredatory adaptations of decapod zoeae. Oecologia 73: 393-400

Naylor, E., Isaac, M. J. (1973). Behavioral significance of pressure responses in megalopa larva of Callinectes sapidus and Macropipus sp. Mar. Behav. Physiol. 1: 341-350

Nichols, P. R., Keney, P. M. (1963). Crab larvae (Callinectes) in plankton collections from M/V Theodore N. Gill, south Atlantic Coast of the United States, 1953-54. Spec. Scient. Rep. U.S. Fish Wildl. Serv. - Fisheries 448: 1-14

NOS (1989). Tidal current tables 1990, Atlantic coast of North America. National Ocean Survey, National Oceanographic and Atmospheric Administration, U.S. Dept of Commerce, Washington, DC

Olmi, E. J. III (1986). Recruitment patterns of selected decapod crustaceans. In: Devoe, M. R., Baughman, D. S. (eds.) South Carolina coastal impoundments: ecological characterization, management, status, and use, Vol. 2. South Carolina Sea Grant Consort., Publ. No. SC-SG-TR-86-2, Charleston, p. 303-360
Olmi, E. J. III. (1993). Immigration of blue crab megalopae in the York River, Virginia: patterns and processes. Ph.D. dissertation, The College of William and Mary, Williamsburg, VA

Olmi, E. J. III, van Montfrans, J., Lipcius, R. N., Orth, R. J., Sadler, P. W. (1990). Variation in planktonic availability and settlement of blue crab megalopae in the York River, Virginia. Bull. mar. Sci. 46: 230-243

Pearre, S. Jr (1973). Vertical migration and feeding in Sagitta elegans Verrill. Ecology 54: 300-314

Pritchard, D. W. (1967). Observations of circulation in coastal plain estuaries. In: Lauff, G. H. (ed.) Estuaries. AAAS Publ. No. 83, Washington, DC, p. 37-44

Provenzano, A. J., McConaugha, J. R., Phillips, K. B., Johnson, D. F., Clark, J. (1983). Vertical distribution of first stage larvae of the blue crab, Callinectes sapidus, at the mouth of the Chesapeake Bay. Estuar. coast. Shelf Sci. 16 489-499

Roughgarden, J., Gaines, S., Possingham, H. (1988). Recruitment dynamics in complex life cycles. Science 241 $1460-1466$

Ryan, B. F., Joiner, B. L., Ryan, T. A. Jr (1985). Minitab handbook, 2nd edn. PWS-Kent, Boston

Sandifer, P. A. (1973). Distribution and abundance of decapod larvae in the York River estuary and adjacent lower Chesapeake Bay, Virginia, 1968-1969. Chesapeake Sci. $14: 235-257$

Sandifer, P. A. (1975). The role of pelagic larvae in recruitment to populations of adult decapod crustaceans in the York River estuary and adjacent lower Chesapeake Bay, Virginia. Estuar. coast. mar. Sci. 3: 269-279

Shanks, A. L. (1988). Further support for the hypothesis that internal waves can cause shoreward transport of larval invertebrates and fish. Fish. Bull. U.S. 86: $703-714$

Smyth, P. O. (1980). Callinectes (Decapoda: Portunidae) larvae in the Middle Atlantic Bight, 1975-77. Fish. Bull. U.S 78: $251-265$

SPSS Inc. (1986). SPSS-X user's guide, 2nd edn. McGraw-Hill, New York

Stancyk, S. E., Feller, R. J. (1986). Transport of non-decapod invertebrate larvae in estuaries: an overview. Bull. mar Sci. 39: 257-268

Stuck, K. C., Perry, H. M. (1981). Observations on the distribution and seasonality of portunid megalopae in Mississippi coastal waters. Gulf Res. Rep. 7: 93-95

Sulkin, S. D. (1984). Behavioral basis of depth regulation in the larvae of brachyuran crabs. Mar. Ecol. Prog. Ser. 15: 181-205

Sulkin, S. D., Phillips, I., Van Heukelem, W. F. (1979). On the locomotory rhythm of brachyuran crab larvae and its significance in vertical migration. Mar. Ecol. Prog. Ser 1: $331-335$

Sulkin, S. D., Van Heukelem, W. F. (1982). Larval recruitment in the crab Callinectes sapidus Rathbun: an amendment to the concept of larval retention in estuaries. In: Kennedy, V. (ed.) Estuarine comparisons. Academic Press, New York, p. $459-475$

Sulkin, S. D., Van Heukelem, W. F. (1986). Variability in the length of the megalopal stage and its consequence to dispersal and recruitment in the portunid crab Callinectes sapidus Rathbun. Bull. mar. Sci. 39: 269-278

Sulkin, S. D., Van Heukelem, W. F., Kelly, P., Van Heukelem, L. (1980). The behavioral basis of larval recruitment in the crab Callinectes sapidus Rathbun: a laboratory investigation of ontogenetic changes in geotaxis and barokinesis Biol. Bull. 159: 402-417 
Tagatz, M. E. (1968). Biology of the blue crab, Callinectes sapidus Rathbun, in the St. Johns River, Florida. Fish. Bull U.S. Fish Wildl. Serv. 67:17-33

Tankersley, R. A., Forward, R. B. Jr (in press). Endogenous swimming rhythms in two estuarine crab megalopae implications for flood tide transport. Mar. Biol.

Tremblay, M. J., Sinclair, M. (1990). Sea scallop larvae Placopecten magellanicus on Georges Bank: vertical distribution in relation to water column stratification and food. Mar. Ecol. Prog. Ser. 61: 1-15

Underwood, A. J. (1981). Techniques of analysis of variance in experimental marine biology and ecology. Oceanogr. mar Biol. A. Rev. 19: 513-605

van Montfrans, J., Peery, C. A., Orth, R. J. (1990). Daily, monthly and annual settlement patterns by Callinectes sapidus and Neopanope sayi megalopae on artificial collectors deployed in the York River, Virginia. Bull. mar. Sci. 46: $214-229$

Wang, D.-P. (1979). Subtidal sea level variations in the Chesa-

This article was presented by K. L. Heck Jr (Senior Editorial Advisor), Dauphin Island, Alabama, USA peake Bay and relations to atmospheric forcing. J. phys Oceanogr. 9: 413-421

Wang, D.-P., Elliott, A. J. (1978). The effect of meteorological forcing on the Chesapeake Bay: the coupling between an estuarine system and its adjacent coastal waters. In: Nihoul, J C. J (ed.) Hydrodynamics of estuaries and fjords. Elsevier, Amsterdam, p 127-145

Wass, M. L. (ed.) (1972). A checklist of the biota of lower Chesapeake Bay. Spec. Sci. Rep. No. 65. Virginia Inst. Mar. Sci., Gloucester Point, VA

Weinstein, M. P., Hodson, R. G., Gerry, L. R. (1980). Retention of three taxa of postlarval fishes in an intensively flushed tidal estuary. Fish. Bull. U.S. 78: 419-436

Williams, A. B. (1971). A ten year study of meroplankton in North Carolina estuaries: annual occurrence of some brachyuran developmental stages. Chesapeake Sci. 12: $53-61$

Zar, J. H. (1984). Biostatistical analysis. Prentice-Hall, Englewood Cliffs, NJ, p. 620

Manuscript first received: May 12, 1993

Revised version accepted: May 31, 1994 